\title{
SOCIO-DEMOGRAPHIC DETERMINANTS OF LOW BIRTH WEIGHT IN NORTHEASTERN CITY, INDIA
}

\section{Nirmali Gogoi.}

Associate Professor (Child Health Nursing), Sankar Madhab College of Nursing, Assam down town University, Guwahati, Assam, India.

\section{ABSTRACT}

Introduction and objectives: Low birth weight is an index of our status of public health, maternal health and nutrition. The major challenge in the field of public health is to identify the factors influencing low birth weight and to institute remedial measures. The study was attempted to assess prevalence of low birth weight and its risk factors affecting low birth weight was conducted among 300 mothers and their respective live born baby in $\mathrm{GMCH}$, Guwahati metro, Assam.

Materials and Methods: A cross sectional study design was carried out in a government hospital among 300 mothers using interviewer administered questionnaire. All 300 postnatal mothers who delivered in the hospital during study period were included in the study except still births. All babies were weighted on standard beam balance within 24 hours of delivery and mother's height was measured by height measuring stand. Bivariate and multivariate logistic regression was employed to identify the predictors at $p<0.001$ and $p<0.05$. Results and analysis: The prevalence of low birth weight was found as $26.0 \%(95 \%, C L=21.36-31.24)$ in 300 samples. Mode of delivery had significant association with Birth weight of newborn, $X^{2}(1, N=300)=7.733$, $P=.005$. Risk of LBW was more than two times as high among mothers with normal delivery than that of Caesarean section $(\mathrm{OR}=2.09 *, 95 \% \mathrm{Cl}: 1.24-3.52)$. Similarly, rural residence( $\mathrm{OR}=1.24,95 \% \mathrm{Cl}: 0.63-2.44)$, illiterate mother ( $O R=1.17,95 \% \mathrm{Cl}: 0.70-1.97)$, illiterate husband ( $\mathrm{OR}=1.09,95 \% \mathrm{Cl}: 0.65-1.82)$, employed mother (OR=2.23, $95 \% \mathrm{Cl}: 0.75-6.64)$, unskilled husbands $(\mathrm{OR}=1.04,95 \% \mathrm{Cl}: 0.53-2.02)$, joint family $(\mathrm{OR}=1.33,95 \% \mathrm{Cl}: 0.75-2.36)$, religion other than Hinduism (OR=1.54, 95\% Cl: $0.87-2.72$ ) and low monthly income less than Rs. 20000 (OR=1.17, $95 \% \mathrm{Cl}: 0.69-1.96)$ were found to be higher risk of LBW.

Discussion and conclusion: The prevalence of low birth weight was found to be very high and it was associated with many risk factors related to maternal health and services. Hence it is recommended to improve maternal health through strengthening the existing maternal services at the basic level of community.

KEY WORDS: Low Birth Weight, Maternal Age, Parity, ANC Visit, HB\% Level, Gestational Age, High Risk Behavior.

Address for correspondence: Ms. Nirmali Gogoi, Associate Professor (Child Health Nursing), Sankar Madhab College of Nursing, Assam down town University, Guwahati, Assam, India. E-Mail: nirmali.gogoi111@gmail.com

\begin{tabular}{|c|c|c|}
\hline \multicolumn{3}{|c|}{ Online Access and Article Informtaion } \\
\hline \multirow{2}{*}{$\begin{array}{l}\text { Quick Response code } \\
\text { Dol: } 10.16965 / \text { ijims.2018.103 }\end{array}$} & \multicolumn{2}{|c|}{$\begin{array}{l}\text { International Journal of Integrative Medical Sciences } \\
\qquad \text { www.imedsciences.com }\end{array}$} \\
\hline & $\begin{array}{l}\text { Received: 31-01-2018 } \\
\text { Reviewed: 31-01-2018 }\end{array}$ & $\begin{array}{l}\text { Accepted: 15-03-2018 } \\
\text { Published: 31-03-2018 }\end{array}$ \\
\hline Source of Funding: Self & \multicolumn{2}{|c|}{ Conflicts of interest: None } \\
\hline
\end{tabular}

\section{BACKGROUND}

Low birth weight is an index of our status of public health, maternal health and nutrition. It is a major factor determining child survival, future physical and mental development and also associated with chronic diseases later in life $[1,2]$. Low birth weight has been defined as birth weight of less than 2500gm (WHO, 1984) [3]. Globally, more than 20 million infants are born with low birth weight. Prevalence of LBW is very high in India (33\%) as compared to developed countries (4.5\%) [4].

According to NFHS-3 data, prevalence of low birth weight is $21.5 \%$ in India [5]. 
Low birth weight is either caused by preterm birth (that is, a low gestational age at birth, commonly defined as younger than 37 weeks of gestation) or the infant being small for gestational age (that is, a slow prenatal growth rate), or a combination of both [6].

Low birth weight is associated with many sociodemographic determinants such as residence (urban-rural), mother's age and occupation, education, parity, sex of baby, antenatal care, maternal height and weight, gestational age of mother, birth order, the family's income and many maternal conditions such as nutritional status, health status.

Low birth weight babies are at greater risk for complications like low oxygen levels at birth, trouble staying warm, trouble feeding and gaining weight, infection breathing problems and immature lungs, nervous system problems and sudden infant death syndrome(SIDS) and also cerebral palsy, blindness deafness and developmental at delay may be long term complications [7].

Prenatal care is extremely essential measure of preventing preterm births and low birth weight babies. Maternal nutrition and maternal health are the most essential aspects of prenatal care.

\section{MATERIALS AND METHODS}

A cross sectional study was carried out in a Government hospital, Guwahati metro, Assam in 2016 from October to December. The study was conducted among 300 mothers using interviewer administered questionnaire. All 300 postnatal mothers who delivered in the hospital during study period were included in the study except still births. The sample size 300 was calculated taking minimum $25 \%$ prevalence of low birth weight with $20 \%$ of permissible error. Consecutive non-random sampling technique was used for selecting samples. Ethical clearance was obtained from the ethical committee of Assam down town University. After obtaining permission from hospital authority and verbal consent was taken from each sample. All babies were weighted on standard beam balance within 24 hours of delivery and mother's height was measured by height measuring stand up to the accuracy of $0.5 \mathrm{~cm}$. LBW was defined as a birth weight of $<2500 \mathrm{gm}$. A predesigned and pretested structured interview schedule related to socio-demographic variables and the maternal risks factors of LBW among post-natal mothers were used for collecting information. The mothers whose were critically ill at the time of data collection and whose mothers had still birth baby were excluded from the study sample. The data collected was compiled, tabulated and subjected to statistical analysis wherever applicable. Statistical analysis was done using SPSS for windows, version 18.0. Bivariate and multivariate logistic regression was employed to identify the predictors at $\mathrm{P}<0.001$, and $\mathrm{p}<0.05$.

\section{RESULTS AND DISCUSSION}

Socio-demographic profile of the Respondents: Birth weight of newborn $>2.5 \mathrm{~kg}$ was $74 \%$, and $<2.5 \mathrm{~kg}$ was $26 \%$. Majority of newborn were male $53 \%$ (159) and majority of baby $88.33 \%$ (265) born before 37 weeks of gestation. Majority of newborns mode of delivery was caesarean section $(60.67 \%)$ as compared to normal delivery (39.33\%). In place of residence, $81.00 \%$ of mothers from rural and $19.00 \%$ from urban. In regards of mother's educational status, $51.67 \%$ of mothers were literate, $48.33 \%$ were Illiterate. $52.33 \%$ of father Literate and $48.33 \%$ were Illiterate. $95.33 \%$ of mothers were housewife and $4.67 \%$ were employed. $81.67 \%$ of fathers were unskilled and $18.33 \%$ skilled workers. $68.67 \%$ of mothers belong to joint family and $31.33 \%$ were nuclear family. $74.33 \%$ of mothers belong to Hindu religion, $24.00 \%$ Muslim and $1.67 \%$ were Christian. Majority of mothers (47.33\%) had Monthly income were Rs. $5001-10,000,43.33 \%$ of mothers had < Rs. 5000 and $9.33 \%$ of mothers had > Rs. 10,000. (Tab-1)

Prevalence of low birth weight: The prevalence of low birth weight in the present study was $26 \%$ (95\% Cl: $21.36 \%-31.24 \%$ ) and $88.33 \%$ of newborns were preterm baby. The normal baby was 74\% (95\% Cl: 68.76\%-78.64\%).(Table-2) This finding is similar to a study conducted by $M$ Krishnatreyal $^{8}$ in Assam (28.40\%) while it is $4 \%-5 \%$ in developed countries (Trivedi and Mavalankar). ${ }^{9}$ Another previous study in Assam conducted by Barua in 1973, the prevalence of LBW among Assamese infants was $45.8 \% .{ }^{10}$ The variation in the prevalence may be due to varying geographic location, socio-cultural and 
socio-economic differences among the different communities.

In present study, the prevalence of low birth weight was high among those mothers residing in rural areas $(65,83 \%)$ whereas it was $71.43 \%$ in study by Dandekar [11], $28 \%$ in study by Swarnatatha N [12]. High prevalence of low birth weight was found among illiterate mothers (42, $53.8 \%)$ while it was low prevalence rate in a study conducted by Rahul et al (5.71\%). Rizvi et al. [13] and Mavalankar et al [14] showed significant association between maternal education and LBW. housewife mothers (72, $92.3 \%)$. Lack of knowledge and awareness regarding the antenatal care, antenatal visits and risk factors may be cause of LBW among illiterate mothers. High prevalence of LBW was found in less than 2000/- monthly income $(42$, although it was not statistically significance, several studies reported similar findings [15-17]. (Table-3)

Socio-demographic determinants of low birth weight: Association between prevalence the low birth weight with demographic variables viz. Mode of delivery, Place of residence, Mother's educational status, Husband's educational status, Mother's occupation, and Husband's occupation, Types of family, Religion and Monthly income were also examined by chi square test of independence. It found none other than Mode of delivery had significant association with Birth weight of newborn, $X^{2}(1, N=300)=7.733, P$ $=.005$. (Table 4)

Normal Mode of delivery was found to be risk of LBW than that of Caesarean section (OR=2.09, $95 \% \mathrm{Cl}: 1.24-3.52)$. Similarly, rural residence (OR=1.24, 95\% Cl: 0.63-2.44), illiterate mother (OR=1.17, 95\% Cl: 0.70-1.97), illiterate husband (OR=1.09, 95\%Cl: 0.65-1.82), employed mother (OR=2.23, 95\% Cl: 0.75-6.64), unskilled husbands (OR=1.04, 95\% Cl: 0.53-2.02), joint family (OR=1.33, 95\% Cl: 0.75-2.36), religion other than
Hinduism (OR=1.54, 95\%Cl: 0.87-2.72) and low monthly income less than Rs. 20000 (OR=1.17, $95 \% \mathrm{Cl}$ : $0.69-1.96)$ were higher risk of LBW of newborn. (Table-4)

An analysis of variance showed that the effect of birth weight of newborn was insignificant on $\mathrm{Hb} \%$ level of mother during delivery, $F(1,298)=$ $0.814, P=0.368$. In other words, mother of low birth weight of newborn $(M=10.23, S D=1.52$, Range: 6.70-14.20) had same $\mathrm{Hb} \%$ level of mothers with normal birth weight of newborn, $(M=10.41, S D=1.50$, Range: $5.10-14.90), t(298)=-$ $.903, P=0.368$ ( two tailed). (Table-5 \&Fig-1) which was indicating that average all mothers were mild anemic (according to WHO classification).

Table 1: Socio-demographic profile of the respondents.

\begin{tabular}{|c|c|c|c|}
\hline VARIABLES & CATEGORIES & FREQUENCY & PERCENTAGE (\%) \\
\hline $\begin{array}{c}\text { Birth weight of } \\
\text { newborn }\end{array}$ & $<2.5 \mathrm{~kg}$ & 78 & $26.00 \%$ \\
\hline & $>2.5 \mathrm{~kg}$ & 222 & $74.00 \%$ \\
\hline Mode of delivery & Normal & 118 & $39.33 \%$ \\
\hline & $\begin{array}{l}\text { Caesarean } \\
\text { section }\end{array}$ & 182 & $60.67 \%$ \\
\hline Place of residence & Urban & 57 & $19.00 \%$ \\
\hline & Rural & 243 & $81.00 \%$ \\
\hline \multirow{2}{*}{$\begin{array}{c}\text { Mother's educational } \\
\text { status }\end{array}$} & Illiterate & 145 & $48.33 \%$ \\
\hline & Literate & 155 & $51.67 \%$ \\
\hline \multirow{2}{*}{\begin{tabular}{|c} 
Husband's \\
educational status
\end{tabular}} & Illiterate & 143 & $47.67 \%$ \\
\hline & Literate & 157 & $52.33 \%$ \\
\hline \multirow{2}{*}{ Mother's occupation } & Housewife & 286 & $95.33 \%$ \\
\hline & Employed & 14 & $4.67 \%$ \\
\hline \multirow{2}{*}{ Husband's occupation } & Unskilled & 245 & $81.67 \%$ \\
\hline & Skilled & 55 & $18.33 \%$ \\
\hline \multirow{2}{*}{ Types of family } & Nuclear & 94 & $31.33 \%$ \\
\hline & Joint & 206 & $68.67 \%$ \\
\hline \multirow{3}{*}{ Religion } & Hindu & 223 & $74.33 \%$ \\
\hline & Muslim & 72 & $24.00 \%$ \\
\hline & Christian & 5 & $1.67 \%$ \\
\hline \multirow{3}{*}{ Monthly income } & $<$ Rs. 5000 & 130 & $43.33 \%$ \\
\hline & $\begin{array}{c}\text { Rs. } 5001- \\
10,000 \\
\end{array}$ & 142 & $47.33 \%$ \\
\hline & $>$ Rs. 10,000 & 28 & $9.33 \%$ \\
\hline Valid & Total & 300 & $100.00 \%$ \\
\hline
\end{tabular}

Table 2: Frequency and descriptive statistics of Birth weight of newborn.

\begin{tabular}{|c|c|c|c|c|c|c|c|}
\hline $\begin{array}{c}\text { Birth weight of } \\
\text { newborn }\end{array}$ & Count & \% & 95\%Cl & Range & Mean & SD & $P$-value \\
\hline$<2.5 \mathrm{~kg}$ & 78 & $26.00 \%$ & $21.36 \%-31.24 \%$ & $6.70-14.20$ & 10.23 & 1.52 & $0.368^{\mathrm{NS}}$ \\
\hline $\mathbf{2 . 5} \mathrm{kg}$ & 222 & $74.00 \%$ & $68.76 \%-78.64 \%$ & $5.10-14.90$ & 10.41 & 1.5 & \\
\hline Total & 300 & $100.00 \%$ & & $5.10-14.90$ & 10.36 & 1.5 & \\
\hline
\end{tabular}

NS =Not Significant 
Table 3: Bivariate cross frequency of socio-demographic factors influencing low birth weight and chi square Test of Association.

\begin{tabular}{|c|c|c|c|c|c|c|c|}
\hline \multirow{2}{*}{\multicolumn{2}{|c|}{ Variables }} & \multicolumn{2}{|c|}{$\begin{array}{l}\text { Birth weight of } \\
\text { newborn }\end{array}$} & \multirow[t]{2}{*}{ Total } & \multirow[t]{2}{*}{ Chi Sq } & \multirow[t]{2}{*}{ df } & \multirow[t]{2}{*}{$P$-value } \\
\hline & & $<2.5 \mathrm{~kg}$ & $\geq 2.5 \mathrm{~kg}$ & & & & \\
\hline \multirow{2}{*}{$\begin{array}{l}\text { Mode of } \\
\text { delivery }\end{array}$} & Normal & 41 & 77 & 118 & \multirow[b]{2}{*}{7.733} & \multirow[b]{2}{*}{1} & \multirow[b]{2}{*}{$0.005^{* *}$} \\
\hline & \begin{tabular}{|c|} 
Caesarean \\
section
\end{tabular} & 37 & 145 & 182 & & & \\
\hline \multirow{2}{*}{$\begin{array}{c}\text { Place of } \\
\text { residence }\end{array}$} & Urban & 13 & 44 & 57 & 0.373 & 1 & $0.541^{\mathrm{NS}}$ \\
\hline & Rural & 65 & 178 & 243 & & & \\
\hline \multirow{2}{*}{$\begin{array}{c}\text { Mother's } \\
\text { educational } \\
\text { status }\end{array}$} & Illiterate & 40 & 105 & 145 & \multirow{2}{*}{0.367} & \multirow{2}{*}{1} & \multirow{2}{*}{$0.545^{\mathrm{NS}}$} \\
\hline & Literate & 38 & 117 & 155 & & & \\
\hline \multirow{2}{*}{$\begin{array}{l}\text { Husband's } \\
\text { educational }\end{array}$} & Illiterate & 36 & 107 & 143 & \multirow{2}{*}{0.097} & \multirow{2}{*}{1} & \multirow{2}{*}{$0.756^{\mathrm{NS}}$} \\
\hline & Literate & 42 & 115 & 157 & & & \\
\hline \multirow{2}{*}{$\begin{array}{c}\text { Mother's } \\
\text { occupation }\end{array}$} & Housewife & 72 & 214 & 286 & \multirow{2}{*}{2.169} & \multirow{2}{*}{1} & \multirow{2}{*}{$0.141^{\mathrm{NS}}$} \\
\hline & Employed & 6 & 8 & 14 & & & \\
\hline \multirow{2}{*}{$\begin{array}{l}\text { Husband's } \\
\text { occupation }\end{array}$} & Unskilled & 64 & 181 & 245 & \multirow{2}{*}{0.01} & \multirow{2}{*}{1} & \multirow{2}{*}{$0.919^{\mathrm{NS}}$} \\
\hline & Skilled & 14 & 41 & 55 & & & \\
\hline \multirow{2}{*}{$\begin{array}{l}\begin{array}{c}\text { Types of } \\
\text { family }\end{array} \\
\text { fol }\end{array}$} & Nuclear & 21 & 73 & 94 & \multirow{2}{*}{0.953} & \multirow{2}{*}{1} & \multirow{2}{*}{$0.329^{\mathrm{NS}}$} \\
\hline & Joint & 57 & 149 & 206 & & & \\
\hline \multirow{3}{*}{ Religion } & Hindu & 53 & 170 & 223 & \multirow{3}{*}{2.684} & \multirow{3}{*}{2} & \\
\hline & Muslim & 24 & 48 & 72 & & & $0.261^{\mathrm{NS}}$ \\
\hline & Christian & 1 & 4 & 5 & & & \\
\hline & $<$ Rs. 5000 & 42 & 94 & 130 & & & \\
\hline Monthly & <Rs. 10000 & 30 & 106 & 142 & 0.529 & 2 & $0.768^{\mathrm{NS}}$ \\
\hline & $\begin{array}{c}>\text { Rs. } \\
10000\end{array}$ & 6 & 22 & 28 & & & \\
\hline To & & 78 & 222 & 300 & & & \\
\hline
\end{tabular}

** Highly significant at $\mathrm{P}(<.01)$, NS =Not Significant

Table 4: Relative Risk Estimates and Odd Ratios Analysis in demographic risk factors for LBW.

\begin{tabular}{|c|c|c|c|c|c|}
\hline \multirow{2}{*}{\multicolumn{2}{|c|}{ Variables }} & \multirow{3}{*}{\begin{tabular}{|c|}
$\begin{array}{c}\text { Odd of outcome } \\
\text { for LBW }\end{array}$ \\
0.53 \\
\end{tabular}} & \multirow{3}{*}{$\begin{array}{c}\text { OR } \\
2.09^{*}\end{array}$} & \multicolumn{2}{|c|}{$95 \% \mathrm{Cl}$} \\
\hline & & & & \multirow{2}{*}{$\frac{\text { Lower }}{1.24}$} & \multirow{2}{*}{$\frac{\text { Upper }}{3.52}$} \\
\hline \multirow{2}{*}{$\begin{array}{l}\text { Mode of } \\
\text { delivery }\end{array}$} & Normal & & & & \\
\hline & $\begin{array}{c}\text { Caesarean } \\
\text { section }\end{array}$ & 0.26 & & & \\
\hline \multirow{2}{*}{$\begin{array}{c}\text { Place of } \\
\text { residence }\end{array}$} & Rural & 0.37 & 1.24 & 0.63 & 2.44 \\
\hline & Urban & 0.3 & & & \\
\hline \multirow{2}{*}{$\begin{array}{l}\text { Mother's } \\
\text { educational } \\
\text { status }\end{array}$} & |lliterate & 0.38 & 1.17 & 0.7 & 1.97 \\
\hline & Literate & 0.32 & & & \\
\hline \multirow{2}{*}{$\begin{array}{c}\text { Husband's } \\
\text { educational } \\
\text { status }\end{array}$} & Literate & 0.37 & 1.09 & 0.65 & 1.82 \\
\hline & |lliterate & 0.34 & & & \\
\hline \multirow{2}{*}{$\begin{array}{c}\text { Mother's } \\
\text { occupation }\end{array}$} & Employed & 0.75 & 2.23 & 0.75 & 6.64 \\
\hline & Housewife & 0.34 & & & \\
\hline \multirow{2}{*}{$\begin{array}{l}\text { Husband's } \\
\text { occupation }\end{array}$} & Unskilled & 0.35 & 1.04 & 0.53 & 2.02 \\
\hline & Skilled & 0.34 & & & \\
\hline \multirow{2}{*}{$\begin{array}{c}\text { Types of } \\
\text { family }\end{array}$} & Joint & 0.38 & 1.33 & 0.75 & 2.36 \\
\hline & Nuclear & 0.29 & & & \\
\hline \multirow{2}{*}{ Religion } & Others & 0.48 & 1.54 & 0.87 & 2.72 \\
\hline & Hindu & 0.31 & & & \\
\hline \multirow{2}{*}{$\begin{array}{l}\text { Monthly } \\
\text { income }\end{array}$} & < Rs. 10000 & 0.38 & 1.17 & 0.69 & 1.96 \\
\hline & >Rs. 10000 & 0.33 & & & \\
\hline \multicolumn{2}{|c|}{ Total } & & & & \\
\hline
\end{tabular}

* Significant at $\mathrm{P}(<.05)$
Table 5: Distribution of Maternal $\mathrm{Hb} \%$ level during delivery.

\begin{tabular}{|c|c|c|c|c|}
\hline Variable & $\mathbf{N}$ & Range & Mean & SD \\
\hline $\begin{array}{c}\text { Hb\% level during } \\
\text { delivery }\end{array}$ & 300 & $5.1-14.9$ & 10.364 & 1.5 \\
\hline Valid N (listwise) & 300 & & & \\
\hline
\end{tabular}

$\mathrm{Hb} \%$ level during delivery

Fig. 1: Analysis of Mean.

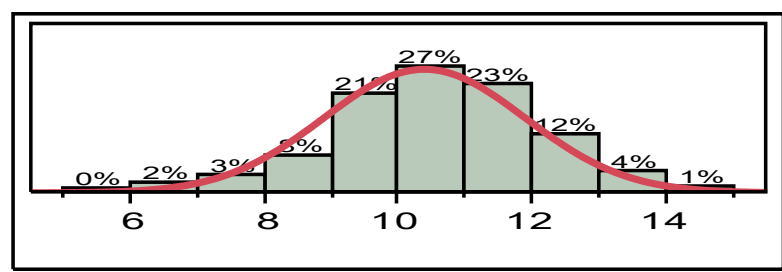

Normal $(10.36,1.50)$

\section{CONCLUSION}

Prevalence of low birth weight was found to be very high in north each India. Maximum newborns were preterm (88.33\%) in present study. Mode of delivery, place of residence, mother's educational status, mother's occupation, religion and monthly income are important socio-demographic factors influencing birth weight of the babies. Maternal education and maternal services like nutrition, sanitation, immunization, through different programme by the governments may improve the birth weight. This may directly influences the mortality and morbidity rates of our country.

\section{ACKNOWLEDGEMENT}

I deeply acknowledge $\operatorname{Dr}$ A. Bhattacharya, Professor and head, Department of Obstetrics and Gynaecology, Guwahati Medical College Hospital, Assam and Authority of the hospital and Ethical Committee of Assam down town University for giving permission to conduct this study.

\section{REFERENCES}

[1]. UNICEF. Low Birth Weight: Country, Regional and Global Estimates. New York: UNICEF; 2004.P1-9.

[2]. Barker DJ. Faetal and Infant Origins of Diseases. London: BMJ Books;1992.

[3]. WHO: the incidence of low birth weight: An update. Weekly Epidemiological Research, 59:205211(1984)

[4]. International Instritute of Population sciences, National family Health Survey, India; 2005-06(NFHS- ${ }^{3}$, vol $_{1}$ ) 2007;223

[5]. UNICEF. The progress of nations, New York, United Nations Children's Fund, 1997. 
[6]. Low birth weight-wikipedia (https;//en.m.w ikiped ia.org >wiki>low)

[7]. Low birth weight-health encyclopedia-university of Rochester medical centre(https;// www.urmc.rochester.edu>content)

[8]. Krishnatreya Mousumi, Ahmed Sajida, Sarma Kabindra Deva. A study to routine antenatal care and its relationship with birth weight in Dimoria Block, kamrup District, Assam. March, Vol.2 Issue:11Page:1621-1629(2015)

[9]. Trivedi CR, Mavalankar DV. Epidemiology of low birth weight in Ahmedabad. IND J Paed 1986; 53:795800.

[10]. Barua A.C. Birth weight in Assamese infants. Ini. J. Pediatr.,10:125-127(1973)

[11]. Rahul Hanumant Dankar, Mahd Shafee, Sati Prasad Sinhna. Prevalence and risk factors affecting low birth weight in adistrict hospital at perambalur, Tamilnadu. Global Journal of medicine and public health. 2014; vol3,issue2

[12]. Swarnalatha N, Bhuvsaneswari P. An epidemiological study of low birth weight in a tertiary care hospital, Tirupati, Andhra Pradesh. IJCRR. 2013;5(16):54-62.
[13]. Rizvi SA, Hatcher J, Jehan I and Qureshi R. maternal risk factors associated low birth weight in Karachi: A case control study. Eastern Mediterranean Health Journal 2007;13(6):1343-52.

[14]. Mavalankar DV, Grey RH, Trivedi CR. Risk factors of preterm and term low birth weight in Ahmedabad. Indian Journal of Epidemiology 1992;21(2):263-72.

[15]. Velankar DH. Maternal factors contributing to low birth weight babies in urban slum community of greater Mumbai. Bombay Hospital Journal. 2009;51(1):26-35

[16]. Kiran A, Garg BS. A study of factors affecting LBW. Indian Journal of Community Medicine 2000;25:5762.

[17]. Sharma MK, Kumar D, Huria A \& Gupta P: Maternal risk factors of low birth weight in Chandigarh India. The internet Jouranal of Health. 20009;9(1):Doi:10.5580/10f1

\footnotetext{
How to cite this article: Nirmali Gogoi. SOCIO-DEMOGRAPHIC DETERMINANTS OF LOW BIRTH WEIGHT IN NORTHEASTERN CITY, INDIA. Int J Intg Med Sci 2018;5(3):587-591. DOI: 10.16965/ ijims.2018.103
} 